Wielicka-Gańczarczyk, K. (2020). Wielowymiarowość przedsiębiorczości w polskiej literaturze naukowej. W: M. Ćwiklicki, K. Sienkiewicz-Małyjurek, (red.). Ekonomia Społeczna. Przedsiębiorczość społeczna w czasie kryzysu (s. 126-137). Kraków: Uniwersytet Ekonomiczny w Krakowie. https://doi.org/10.15678/ES.2020.2.11

\title{
Wielowymiarowość przedsiębiorczości w polskiej literaturze naukowej
}

\begin{abstract}
Karolina Wielicka-Gańczarczyk
Streszczenie: Wykazanie wzajemnego przenikania się różnych podejść do definiowania przedsiębiorczości i ich rodzajów, ze szczególnym zwróceniem uwagi na przedsiębiorczość publiczną, jako obszar występowania wszystkich typów przedsiębiorczości. Artykuł o charakterze przeglądowym, stanowi rezultat kwerendy aktualnej literatury przedmiotu w zakresie podjętego problemu, w opracowaniu posłużono się również wnioskowaniem dedukcyjnym oraz techniką mapy myśli. Na podstawie przeprowadzonej analizy literatury wykazano wielowymiarowość pojęcia przedsiębiorczości. W literaturze przedmiotu podejmowano wiele prób związanych z coraz większym zawężaniem tego pojęcia, na co wskazują m.in. rodzaje przedsiębiorczości będące obiektem rozważań naukowców. Pojęcie przedsiębiorczości jest pojęciem wielowymiarowym i może być rozpatrywane przez pryzmat wszystkich aspektów życia człowieka, jak również funkcjonowania przedsiębiorstw. Badania prowadzone na temat przedsiębiorczości powinny odnosić się do trzech wymiarów, tj. indywidualnych cech osobowych, organizacji oraz wzajemnego wpływu organizacji na człowieka (nie tylko pracownika) i człowieka na organizację.
\end{abstract}

Słowa kluczowe: przedsiębiorczość; rodzaje przedsiębiorczości; przedsiębiorczość publiczna

Kody JEL: $\quad$ L26, L30

\section{Wstęp}

Literatura przedmiotu bogata jest w interpretacje pojęcia przedsiębiorczości, wyszczególnia jej bariery, przesłanki oraz dzieli na rodzaje. Przyjmując, że przedsiębiorczość odnosi się do podejmowania działań, nakreślania drogi dalszego rozwoju oraz efektywności zarządzania (Sułkowski, Marjański, 2017, s. 7) można wykazać, że opiera się ona na naukach o zarządzaniu i jakości. Zawężenie interpretacji pojęcia do jednej dyscypliny naukowej nie prowadzi do uzyskania ogólnie akceptowalnej przez naukowców definicji. Mnogość podejść w definiowaniu przedsiębiorczości powoduje, że jest ona pojęciem wielowątkowym. W obszarze organizacyjnym skupia się na procesach znajdywania i wykorzystywania okazji, z kolei gdy dotyczy człowieka jej uwaga koncentruje się na jego zdolnościach, posiadanych warunkach i ogólnych predyspozycjach do uczestniczenia w procesie znajdywania i wykorzystywania szans (Baran, Bąk, 2016, s. 83).

Celem nin. artykułu jest usystematyzowanie wiedzy z zakresu przedsiębiorczości oraz wykazanie wzajemnego przenikania się różnych podejść do jej definiowania i jej rodzajów, ze szczególnym zwróceniem uwagi na przedsiębiorczość publiczną jako obszaru występowania wszystkich typów przedsiębiorczości. Do realizacji wskazanego celu posłużono się studium literaturowym, wnioskowaniem dedukcyjnym oraz techniką mapy myśli. Przyjęty w niniej- 
szym opracowaniu problem badawczy jest zarówno aktualny, jak i interesujący, szczególnie wobec niewystarczającego rozpoznania problematyki przedsiębiorczości w polskiej literaturze w odniesieniu do obszaru ekonomii społecznej.

\section{Przegląd literatury - przedsiębiorczość i jej rodzaje}

Nie ulega wątpliwości, że przedsiębiorczość można odnieść do czterech kategorii, a mianowicie (Piwowar-Sulej, Kwil, 2018, s. 19):

- psychologicznej, uwzględniającej indywidualne cechy osobowości osób zarządzających przedsiębiorstwem,

- ekonomicznej, która przejawia się dążeniem do wzrostu osiąganych przychodów,

- menadżerskiej, odnoszącej się do różnorodności stylów zarządzania,

- społeczno-kulturowej, która obrazuje powiazanie norm kulturowych społeczeństwa z przedsiębiorczością.

Z kolei zdaniem K. Wach $(2015$, s. 26) przedsiębiorczość odnosi się do cech osobowości menedżerów i działań podejmowanych przez tych menedżerów, organizacje i rynek (funkcje przedsiębiorczości). Według M. Huczek (2018, s. 20) definicje przedsiębiorczości ujęte w literaturze naukowej mogą być rozpatrywane w trzech kategoriach, tj. czego lub kogo dotyczy przedsiębiorczość, do jakiego typu organizacji odnosi się oraz z jakich powodów podjęto rozważania nad w tym zakresie. W przypadku pierwszej kategorii wyszczególniono dwa podejścia. Pierwsze z nich, podejście przedmiotowe, rozpatruje przedsiębiorczość w ujęciu indywidualnych cech odnoszących się do ludzi lub organizacji (jak np. kultura organizacyjna). W podejściu drugim - podmiotowym, przedsiębiorczość dotyczy aktywności przedsiębiorstw. Kryterium drugie uwzględnia typ badanego podmiotu, analizując przedsiębiorczość w zależności od przynależności do danego sektora np. przedsiębiorczość akademicka. Ostatnie, trzecie kryterium, odnosi się do natury, sposobu przedstawienia celów badawczych, dla których podejmowane są rozważania nad przedsiębiorczością. M. Huczek (2018) wyróżnił tutaj cztery sposoby ujmowania celów, tj. opisowy, eksplikacyjny, diagnostyczny i normatywny. Inna grupa badaczy nierozerwalnie wiążę przedsiębiorczość z innowacyjnością. Uznają ją oni, w myśl J. Klich, za „entuzjastyczną wiarę w innowacyjność i generowanie pomysłów, które są z pasją realizowane w celu osiągnięcia ponadprzeciętnych korzyści" (Polcyn, 2014, s. 158).

W literaturze przedmiotu wyróżnia się wiele rodzajów przedsiębiorczości zależnych chociaż by od tego, czy dotyczy ona człowieka, czy organizacji. Należy zatem zadać pytanie, czy podział ten jest pełny i wyczerpuje wielowymiarowość pojęcia przedsiębiorczości?

\section{Metodyka badawcza}

Celem niniejszego artykułu jest usystematyzowanie wiedzy z zakresu rodzajów przedsiębiorczości oraz wykazanie wzajemnego przenikania się różnych podejść w zakresie definiowania przedsiębiorczości i jej rodzajów. Do realizacji wyżej wskazanego celu posłużono się studium literaturowym, wnioskowaniem dedukcyjnym oraz techniką mapy myśli. Badania przeprowadzono w sierpniu 2020 r. z wykorzystaniem ogólnodostępnej, darmowej bazy zawierającej publikacje naukowe, tj. Google Scholar. Proces badawczy składał się z 5 etapów.

Pierwszy etap obejmował wstępną analizę krajowej literatury w oparciu o następujące słowa klucze występujące w treści lub tytule publikacji: przedsiębiorczość, przedsiębiorczości, czy wielowymiarowość. Okres analizy uwzględniał publikację nie starsze niż 5 lat, tj. wydane 
między 2015 rokiem a 2020. W wyniku prac przeprowadzonych w etapie I łącznie zidentyfikowano 899 wyników.

W drugim etapie dokonano wstępnej selekcji publikacji. Etap obejmował wykluczenie z dalszej analizy publikacji dublujących się, co pozwoliło na zawężenie bazy do 690 wyników.

W kolejnym etapie odrzucono publikacje, które znalazły się w bazie, ale nie stanowiły treści naukowych, jak np. studenckie prace zaliczeniowe, założenia programów jednostek samorządów terytorialnych itp. oraz takie, dla których słowa klucze występowały w piśmiennictwie. Po dokonaniu selekcji uzyskano 572 wyniki.

\section{Tabela 1. Wykaz publikacji o największej liczbie cytowań}

\begin{tabular}{|c|c|c|c|c|}
\hline Autor & Tytułpublikacji & $\begin{array}{c}\text { Rok } \\
\text { wydania }\end{array}$ & Rodzaj publikacji & $\begin{array}{l}\text { Liczba } \\
\text { cytowań }\end{array}$ \\
\hline K. Wach & $\begin{array}{l}\text { Przedsiębiorczość jako czynnik rozwoju społeczno- } \\
\text {-gospodarczego: przegląd literatury }\end{array}$ & 2015 & przegląd literatury & 47 \\
\hline D. Piróg & $\begin{array}{l}\text { Kompetencje z zakresu przedsiębiorczości: rozważania } \\
\text { teoretyczne i ich ilustracje w obszarze szkolnictwa } \\
\text { wyższego }\end{array}$ & 2015 & przegląd literatury & 32 \\
\hline $\begin{array}{l}\text { M. Płaziak, } \\
\text { T. Rachwał }\end{array}$ & $\begin{array}{l}\text { „Przedsiębiorczy region”-zarys koncepcji w świetle } \\
\text { analizy roli przedsiębiorczości w krajowej strategii } \\
\text { rozwoju regionalnego }\end{array}$ & 2015 & studium przypadku & 20 \\
\hline $\begin{array}{l}\text { M. Bajgier-Kowalska, } \\
\text { M. Tracz, R. Uliszak }\end{array}$ & $\begin{array}{l}\text { Uwarunkowania rozwoju przedsiębiorczości na obszarach } \\
\text { wiejskich na przykładzie gospodarstw agroturystycznych } \\
\text { województwa małopolskiego }\end{array}$ & 2016 & $\begin{array}{l}\text { przegląd literatury, } \\
\text { analiza danych } \\
\text { statystycznych }\end{array}$ & 17 \\
\hline Z. Zioło & Przedsiębiorczość w rozwoju układów lokalnych & 2016 & artykuł koncepcyjny & 15 \\
\hline K. Bratnicka & Twórcza przedsiębiorczość organizacyjna & 2015 & przegląd literatury & 14 \\
\hline J. Jeżak & $\begin{array}{l}\text { Rozwój przedsiębiorczości rodzinnej w Polsce na tle } \\
\text { tendencji światowych }\end{array}$ & 2016 & artykułbadawczy & 14 \\
\hline J. Bański & $\begin{array}{l}\text { Uwarunkowania rozwoju przedsiębiorczości na wsi- } \\
\text { wybrane zagadnienia }\end{array}$ & 2015 & artykuł badawczy & 13 \\
\hline M. Sadowska & $\begin{array}{l}\text { Edukacja w zakresie przedsiębiorczości w polskim syste- } \\
\text { mie kształcenia oraz w państwach europejskich }\end{array}$ & 2016 & artykuł analityczny & 11 \\
\hline A. Pacut & $\begin{array}{l}\text { Rozwój przedsiębiorczości społecznej-istota i kierunki } \\
\text { analizy }\end{array}$ & 2015 & przegląd literatury & 11 \\
\hline $\begin{array}{l}\text { M. Roman, } \\
\text { A. Niedziółka }\end{array}$ & $\begin{array}{l}\text { Agroturystyka jako forma przedsiębiorczości na obsza- } \\
\text { rach wiejskich }\end{array}$ & 2017 & $\begin{array}{l}\text { publikacja badawcza } \\
\text { przegląd literatury }\end{array}$ & 10 \\
\hline $\begin{array}{l}\text { A. Gaweł, } \\
\text { M. Pietrzykowski }\end{array}$ & $\begin{array}{l}\text { Edukacja akademicka w postrzeganiu przedsiębiorczości i } \\
\text { kształtowaniu intencji przedsiębiorczych }\end{array}$ & 2015 & artykułbadawczy & 10 \\
\hline $\begin{array}{l}\text { J.W. Pietrewicz, } \\
\text { R. Sobiecki }\end{array}$ & Przedsiębiorczość sharing economy & 2016 & $\begin{array}{l}\text { przegląd literatury } \\
\text { artykuł analityczny }\end{array}$ & 10 \\
\hline M. Tracz & $\begin{array}{l}\text { Przedmiot podstawy przedsiębiorczości w opinii uczniów } \\
\text { i nauczycieli-studium porównawcze }\end{array}$ & 2015 & artykuł badawczy & 10 \\
\hline J. Stachowicz & $\begin{array}{l}\text { Przedsiębiorczość technologiczna kluczową siłą rozwoju } \\
\text { przedsiębiorstw wysokich technologii }\end{array}$ & 2015 & artykuł koncepcyjny & 10 \\
\hline
\end{tabular}

Źródło: opracowanie własne. 
W następnym kroku do dalszej analizy wybrano publikację, które zostały zacytowane więcej niż dwa razy, co pozwoliło na uzyskanie 108 wyników. Wykaz publikacji o największej liczbie cytowani przedstawiono w tabeli 1. Publikacje zawarte w tabeli 1 zostały uporządkowane według liczby cytowań, od największej do najmniejszej.

Uzyskany w ten sposób zbiór publikacji poddano analizie abstraktów i skanowaniu tekstów, co pozwoliło na wyeliminowanie publikacji nie związanych z obszarem badawczym. Proces ten umożliwił zidentyfikowanie 101 publikacji, na podstawie, których wyłoniono najczęściej analizowane rodzaje przedsiębiorczości oraz obszary podlegające badaniom.

$\mathrm{Na}$ uwagę zasługuje fakt, że nieliczne $\mathrm{z}$ analizowanych publikacji naukowych (wydane w ciągu ostatnich 5 lat, zacytowane więcej niż dwa razy) odnoszą się do kryzysu, sytuacji kryzysowych, czy zarządzania kryzysowego. Po wpisaniu słów kluczy "przedsiębiorczo* kryzys* w bazie Google Scholar uzyskano 6650 wyników, w których słowa klucze występują w dowolnym miejscu w tekście. Po ograniczeniu wyszukiwania ww. słów do tytułów publikacji nie uzyskano żadnego wyniku.

Po dokonaniu analizy wstępnej stu pierwszych publikacji i odrzuceniu tych, które nie zawierały wymaganych słów kluczowych (przykładowo słowa klucze znajdowały się w pozycjach bibliograficznych) oraz odpowiedniej liczby cytowani, uzyskano jedynie trzy wyniki spełniające przyjęte kryteria (tabela 2). Publikacje zawarte w tabeli 2 zostały uporządkowane według liczby cytowań, od największej do najmniejszej.

Tabela 2. Wykaz publikacji zawierających słowa kluczowe „przedsiębiorczo* kryzys*” o największej liczbie cytowań

\begin{tabular}{|c|c|c|c|c|}
\hline Autor & Tytuł publikacji & $\begin{array}{c}\text { Rok } \\
\text { wydania }\end{array}$ & Rodzaj publikacji & $\begin{array}{l}\text { Liczba } \\
\text { cytowań }\end{array}$ \\
\hline A. Walecka & Kapitał relacyjny przedsiębiorstw w kryzysie & 2016 & artykuł badawczy & 11 \\
\hline A. Chodyński & $\begin{array}{l}\text { Interesariusze w kształtowaniu bezpieczeństwa organi- } \\
\text { zacji wobec kryzysu pozaekonomicznego }\end{array}$ & 2016 & $\begin{array}{l}\text { przegląd literatury } \\
\text { artykuł koncepcyjny }\end{array}$ & 6 \\
\hline M. Zastempowski & $\begin{array}{l}\text { Innowacyjność małych i średnich przedsiębiorstw } \\
\text { w warunkach kryzysu gospodarczego }\end{array}$ & 2016 & przegląd literatury & 5 \\
\hline
\end{tabular}

Źródło: opracowanie własne.

Powyższe publikacje odnoszą się m.in. do kryzysu gospodarczego, pozagospodarczego i twórczej destrukcji. W publikacjach obszary te są traktowane jako czynniki wpływające na pobudzanie konkurencyjności między organizacjami, czy wyzwalające innowacyjność i przedsiębiorczość.

\section{Wyniki przeprowadzonych badań}

Analiza 101 publikacji z zakresu przedsiębiorczości pozwoliła zauważyć, że termin ten jest analizowany przez badaczy w trzech perspektywach tj. z perspektywy cech indywidualnych człowieka (26 publikacji), organizacji (33 publikacje) i wzajemnych relacji między człowiekiem a organizacją (35 publikacji).

Kolejne rozważania odnoszą się do coraz bardziej szczegółowych podziałów przedsiębiorczości. Poddane analizie publikacje dotyczyły najczęściej przedsiębiorczości gospodarczej (18 publikacji), administracyjnej/publicznej (15 publikacji), akademickiej (13 publikacji) oraz 
społecznej (9 publikacji). Badacze analizowali przedsiębiorczość w aspekcie regionów wiejskich i turystyki w regionie (24 publikacje, spośród których 14 ukazało się w 2015 r.). Następnym szeroko analizowanym obszarem przedsiębiorczości pod względem liczby publikacji była edukacja zarówno szkolna jak i uniwersytecka (14 publikacji, spośród których 4 opublikowano w 2015 r., 7 w 2016 r. i 3 w 2018 r.). Kolejne obszary uzyskały 5 wyników (np. MŚP) lub mniej niż 5 wskazań (np. innowacje - 4 publikacje, internacjonalizacja - 3, przegląd literatury z zakresu przedsiębiorczości - 3, współdzielenie - 2).

Na rysunku 1 podjęto próbę podziału rodzajów przedsiębiorczości w ujęciu przedmiotowym, podmiotowym i mieszanym. Schemat przedstawiony na rysunku 1 przedstawia opisywane rodzaje przedsiębiorczości, a w nawiasach ujęto liczbę publikacji dotyczących danego obszaru.

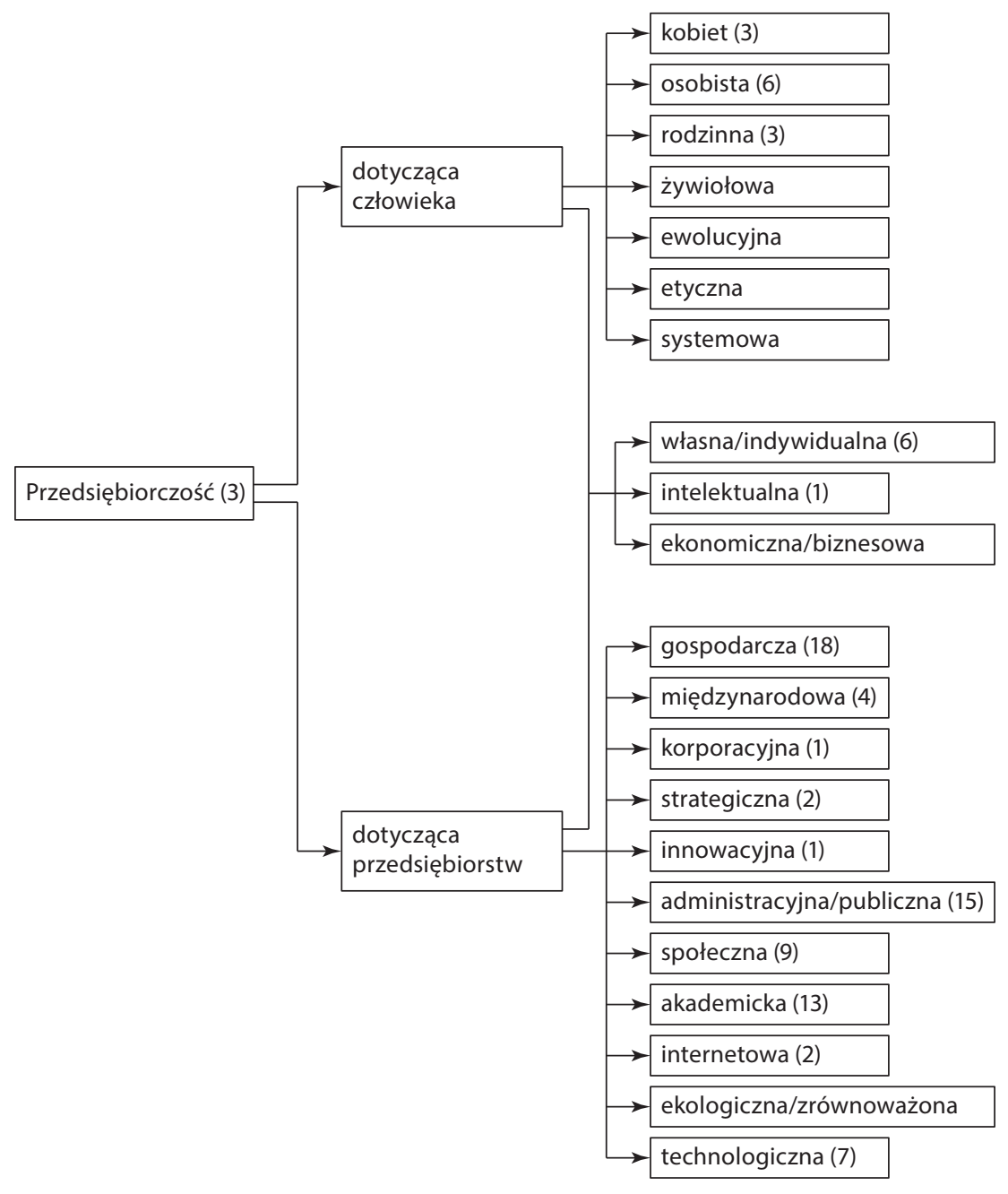

Rysunek 1. Rodzaje przedsiębiorczości 
Klasyfikacja przedsiębiorczości przedstawiona na rysunku 1 uwzględnia podział na człowieka i przedsiębiorstwo. Pierwszy z tych obszarów koncentruje się na działaniach człowieka i odnosi się do jego indywidualnych decyzji mających wpływ na jego życie. W drugim obszarze rozważania odnoszą się do przedsiębiorstwa i są rozpatrywane z punktu widzenia decyzji podejmowanych przez pracowników, które mają wpływ na dalszy rozwój działalności tego przedsiębiorstwa. Dodatkowo zaproponowano podejście mieszane, które przedstawiono na przykładzie interpretacji przedsiębiorczości indywidualnej, intelektualnej i biznesowej.

Pierwsza widoczna klasyfikacja przedsiębiorczości w ujęciu człowieka zwraca uwagę na podział ze względu na płeć, odnosząc się jedynie do kobiet. Należy zaznaczyć, że w literaturze przedmiotu brakuje definicji pojęcia przedsiębiorczość kobiet (czy inaczej przedsiębiorczość żeńska), tym bardziej nie jest popularnym pojęcie przedsiębiorczość mężczyzn, czy przedsiębiorczość męska.

W aspekcie przedsiębiorczości człowieka L. H. Haber (Gromada, 2016, s. 10) wyróżnił cztery rodzaje przedsiębiorczości tj. żywiołową, ewolucyjną, etyczną i systemową. Pierwsza z nich charakteryzuje się nieodpartą potrzebą dążenia do sukcesu, która może prowadzić do podejmowania działań ryzykownych. Jej przeciwieństwem jest przedsiębiorczość etyczna, w myśl której podejmowane działania mają charakter rozważny i logiczny. Przedsiębiorczość ewolucyjna opiera się na stopniowym rozwoju człowieka, jego umiejętnościach i doświadczeniu. Przedsiębiorczość systemowa polega na prowadzeniu przez państwo polityki sprzyjającej rozwojowi przedsiębiorczości w społeczeństwie akcentując kreatywność i innowacyjność, a zatem tworzy mechanizmy pozwalające człowiekowi na rozpoczęcie własnej działalności gospodarczej (Gąszczyk, 2015, s. 74). Ze względu na to, że przedmiotem rozważań przedsiębiorczości systemowej jest człowiek została ona zakwalifikowana do przedsiębiorczości odnoszącej się do zachowań ludzkich, państwo w tym procesie stanowi czynnik wejścia w procesie wykorzystywania okazji. Żadna z powyżej przytoczonych przedsiębiorczości nie była przedmiotem badań naukowców w latach 2015-2020. W przypadku 6 publikacji wskazano na przedsiębiorczość osobistą, która może być przedmiotem rozważań również w aspekcie pozostałych rodzajów przedsiębiorczości odnoszących się do człowieka.

W drugiej klasyfikacji, w której przedmiotem dociekań jest przedsiębiorstwo widać dużo bardziej szczegółowy sposób skategoryzowania przedsiębiorczości. Pierwszy podział oddaje skalę zjawiska. Uwzględnia się w nim przedsiębiorczość gospodarczą, międzynarodową, korporacyjną i własną. Najogólniej można przyjąć, że przedsiębiorczość gospodarcza dotyczy wszelkich przejawów aktywności w zakresie prowadzenia przedsiębiorstwa (Wuwer, 2018, s. 515) nastawionego na generowanie zysku (Faron, Maciejewski, 2018, s. 515). W aspekcie międzynarodowym, przedsiębiorczość oznacza prowadzenie działalności gospodarczej poza granicami kraju (Daszkiewicz, 2014, s. 2014). Jedynie 2 publikacje spośród analizowanych dotyczyły internacjonalizacji przedsiębiorstw, pozostałe 2 koncentrowały się na analizie literatury oraz MŚP. Przedsiębiorczość korporacyjna odnosi się działań, przeważnie o charakterze innowacyjnym, podejmowanych przez kierownictwo i pracowników korporacji. Z punktu widzenia naukowego, zainteresowania badaczy w aspekcie przedsiębiorczości korporacyjnej koncentrują się na określeniu wpływu przedsiębiorstwa (np. jego kultury organizacyjnej, atmosfery w pracy itp.) na przedsiębiorczość jego pracowników (Piecuch, 2018, s. 6-7). Najniższym rodzajem przedsiębiorczości uwzględniającym rozmiar organizacji jest przedsiębiorczość własna/ indywidualna, dotycząca mikroprzedsiębiorstw (4 publikacje), czy samozatrudnienia (2 publikacje). Ze względu na swoją specyfikę łączy ona zarówno aspekty związane z człowiekiem, jak i z przedsiębiorstwem. Dotyczy indywidualnych cech osobowościowych człowieka, który 
występuje w roli przedsiębiorcy oraz odnosi się do całego przedsiębiorstwa, pokazując wpływ cech indywidualnych na jego rozwój (Nowicka, 2014, s. 131).

Przy tej sposobności warto podjąć rozważania dotyczące przedsiębiorczości intelektualnej, która ma podobny charakter interpretacyjny jak w przypadku przedsiębiorczości własnej, charakteryzując się dwoistością interpretacji. Z jednej strony odnosi się do intelektu człowieka, którego źródłem jest jego wiedza (Chyba, 2015, s. 31), a z drugiej może dotyczyć przedsiębiorstw uczących się, opartych na wiedzy, czy inteligentnych.

Można by pomyśleć, że przedsiębiorczość ekonomiczna związana jest z rozwojem organizacji, wzrostem jej przychodów w wyniku podejmowania odpowiednich decyzji. Dotyczy ona jednakże cech ludzkich takich jak np. śmiałość, odwaga, wewnętrzna motywacja i odnosi się do podejmowania decyzji o założeniu biznesu, zarządzaniu firmą, czy realizacji przedsięwzięcia bez wystarczającego zaplecza finansowego (Bieniok, 2016, s. 161).

Przedsiębiorczość strategiczna to zmiany w sposobie funkcjonowania przedsiębiorstwa, przekształcenie kluczowych wartości, idei, wokół których budowana jest nowa strategia i nowa pozycja konkurencyjna (Bratnicka, 2015, s. 31). Przedsiębiorczość innowacyjna w wąskim znaczeniu tego pojęcia może dotyczyć inkubatorów przedsiębiorczości, centrów transferu technologii, centrów innowacji itp. (Mijal, 2016, s. 47), ale może również uwzględniać podejmowanie działań o charakterze innowacyjnym.

Przedsiębiorczość społeczna związana jest z poszukiwaniem nowych możliwości, strategii finansowania działalności non profit lub programów mających na celu tworzenie wartości społecznej (Popowska, 2018, s. 207). Można zatem stwierdzić, że w dużej mierze jest kreowana przez politykę państwa i działalność organizacji pozarządowych (w przypadku 2 publikacji odnosiła się do funduszy unijnych).

Przedsiębiorczość akademicka obejmuje z kolei działania mające na celu zapewnienie współpracy pomiędzy wiedzą a praktyką poprzez propagowanie zachowań i postaw przedsiębiorczych (Strojny, Chodober, 2016, s.418). Publikacje z tego zakresu koncentrowały się przede wszystkim na postawie nauczyciela akademickiego, narzędziach i technikach przekazywania wiedzy (5 publikacji), ale również dotyczyły szkół ponadgimnazjalnych, postaw nauczycieli i uczniów względem przedsiębiorczości.

Przedsiębiorczość internetowa to działania podejmowane przez przedsiębiorstwo z wykorzystaniem technologii internetowych (Roslan-Karaś, Wasilczuk, 2015, s. 151), zatem jest ona związana z prowadzeniem e-biznesu. Jedynie 2 publikacje koncentrowały się na tym obszarze i dotyczyły możliwość ograniczenia chaosu informacyjnego.

Przedsiębiorczość ekologiczna to pojęcie, które pojawiło się w latach 90 XX w., a jego rolą jest integracja celów związanych z prowadzeniem działalności gospodarczej ze zrównoważonym rozwojem uwzględniającym aspekty środowiskowe, ekonomiczne i społeczne (Urbaniec, 2018, s. 27). Wśród analizowanych publikacji nie znalazła się żadna, która poruszałaby ten rodzaj przedsiębiorczości.

W przypadku 7 publikacji pojawiły się odniesienia do następujących form, czy rodzajów przedsiębiorczości, tj. przedsiębiorczości twórczej, regionalnej, małych przedsiębiorstw, organizacyjnej i komunalnej. Nieliczne z analizowanych publikacji naukowych, wydanych w ciągu ostatnich 5 lat i zacytowanych więcej niż dwa razy, odnosiły się do sytuacji kryzysowych.

Wielowymiarowość przedsiębiorczości dobrze uwidacznia przykład przedsiębiorczości publicznej, nad którą początki rozważań sięgają połowy lat 80. XX w. Przedsiębiorczość publiczna jest tu traktowana jako proces „aktywnego poszukiwania rozwiązań zmierzających do zaspokojenia potrzeb obywateli" (Ćwiklicki, 2015, s. 9). W ujęciu wewnętrznym, przedsiębior- 
czość publiczna odnosi się do procesu tworzenia wartości dla obywatela (wartości społecznej, czy inaczej wartości publicznej) na skutek współpracy, interakcji pomiędzy zasobami z sektora publicznego i prywatnego, które są użytkowane w celu znalezienia i wykorzystania pojawiających się okazji (Wodecka-Hyjek, 2018, s. 456). Na proces ten składa się wiele czynników, które mogą być opisane poprzez wykorzystanie odrębnych rodzajów przedsiębiorczości, tj. przedsiębiorczość kobiet/mężczyzn, indywidualna, ekonomiczna, społeczna, akademicka itp.

Zważywszy na to, że powyżej przytoczona definicja odnosi się do pojęcia wartości społecznej, czy też wartości publicznej, warto zastanowić się nad ich znaczeniem. Najogólniej można stwierdzić, że wartością publiczną są wszelkiego rodzaju usługi lub świadczenia, na które społeczeństwo zgłasza zapotrzebowanie. Przedsiębiorczość publiczna w dużej mierze opiera się na udzielaniu usług lub świadczeń (np. edukacja, opieka zdrowotna itp.) przez podmioty reprezentujące władzę publiczną. Tworząc zatem usługę o wartości publicznej należy kierować się efektem, jaki może ona przynieść społeczeństwu, a nie możliwym do osiągnięcia zyskiem, czy generowanym przez nią kosztem wytworzenia, które jest trudny do wyceny (Musialik, Musialik, 2015, s. 174). Kwestia zaufania jest tutaj nadrzędna, ponieważ korzystanie z usług publicznych, nierzadko wrażliwych społecznie (np. zdrowie, bezpieczeństwo, szkolnictwo), wskazuje pośrednio na zaufanie obywateli do władzy (Wiśniewska, 2018, s. 112). Można tym samym stwierdzić, że przedsiębiorczość, jako działalność zmierzająca do wytworzenia wartości publicznej, jest tutaj rozumiana jako siła sprawcza warunkująca rozwój, kreująca siłę podaży i popytu, czy wyznaczająca konkurencyjność na danym rynku. Ujęcie to wymusza konieczność analizowania przedsiębiorczości przez pryzmat zależności od zjawisk, czy procesów politycznych i gospodarczych (Wodecka-Hyjek, 2012, s. 426).

Inne definicje przedsiębiorczości publicznej zwracają uwagę na jej połączenie z innowacyjnością. Działalność innowacyjna może dotyczyć wspierania nowych pomysłów, czy też wdrożenia nowych technologii lub tworzenia nowych produktów (Głód, Głód, 2017, s. 75) i może być częścią strategii funkcjonowania organizacji publicznej (Sasinowski, 2015, s. 86). W literaturze przedmiotu, oprócz badań nad zależnością przedsiębiorczości publicznej od innowacyjności, można znaleźć rozważania obejmujące zdolność organizacji publicznych do osiągania zysku, czy podejmowania decyzji w niepewnych warunkach działania (Wodecka-Hyjek, 2018, s. 456). Wskazane powyżej przykładowe obszary zainteresowań badaczy w zakresie przedsiębiorczości publicznej pozwalają stwierdzić, że jest ona w dużej mierze zbliżona do przedsiębiorczości rozumianej przez pryzmat podmiotów komercyjnych. Zarówno w pierwszym jak i w drugim przypadku polega ona na (Kowalczyk, 2015, s. 473):

- zauważeniu, znalezieniu i wykorzystaniu pojawiającej się w otoczeniu szansy/okazji,

- kreowaniu nowych wartości,

- realizowaniu przedsięwzięć m.in. polegających na powołaniu nowej działalności gospodarczej, wdrożeniu lub zaprojektowaniu rozwiązań innowacyjnych itp.

Jako główne różnice pomiędzy przedsiębiorczością organizacji należących do sektora publicznego a tych z sektora prywatnego, należy wyszczególnić mniejsze zainteresowanie zyskiem oraz mniejszą swobodę w działaniu (Wodecka-Hyjek, 2018, s. 455). Współczesne teorie przedsiębiorczości publicznej podkreślają, że nie jest ona domeną wyłącznie sektora publicznego, a wręcz odnosi się do wszystkich rodzajów organizacji niezależnie od tego, czy ich celem jest zysk, czy działalność non-profit (Sikorska-Wolak, Cyburt, 2015, s. 108). Pogląd ten wydaje się być spójny w przypadku analizowania przedsiębiorczości publicznej przez pryzmat kryterium własności, który pozwala na rozszerzenie rozważań o inne podmioty, nie tylko te stricte należące do sektora publicznego, jak państwowe i samorządowe jednostki organizacyjne. Badanie 
sektora publicznego według kryterium własności pozwala rozszerzyć ilość podmiotów badawczych o te, dla których właścicielem są np. jednostki samorządu terytorialnego. Wśród takich podmiotów, w myśl art. 6, pkt. 1 ustawy o działalności leczniczej, można wyszczególnić chociażby szpitale działające jako np. spółki kapitałowe.

Powyżej przedstawione przykłady interpretacji różnych rodzajów przedsiębiorczości uwidaczniają wzajemne przenikanie się podejścia przedmiotowego i podmiotowego zarówno w interpretacji definicyjnej, jak i w sposobie prowadzenia badań.

\section{Zakończenie}

Literatura przedmiotu bogata jest w różnorodne podejścia i interpretacje pojęcia przedsiębiorczości. Poddając analizie definicje różnych rodzajów przedsiębiorczości można zauważyć brak jednoznaczności, czy odnoszą się one do ludzi (np. przedsiębiorców, pracowników), czy do organizacji. Niejednokrotnie interpretacja ma zastosowanie zarówno w jednym jak i w drugim przypadku np. przedsiębiorczość intelektualna może odnosić się do człowieka, ale również do organizacji uczących się. W większości analizowanych prac naukowych z zakresu przedsiębiorczości te dwa podejścia nie przenikają się, a badacze koncentrują się albo na cechach osobowych przedsiębiorcy, albo na procesie wykorzystywania okazji w celu rozwoju przedsiębiorstwa. Brak zatem pokazania wielowymiarowości pojęcia przedsiębiorczości i wzajemnego przenikania się jego podejść.

Przedsiębiorczość jest pojęciem wielowymiarowym i może być rozpatrywana przez pryzmat wszystkich aspektów życia człowieka, jak również funkcjonowania przedsiębiorstw. Niemniej badacze rozpatrują ją w ujęciu podmiotowym lub przedmiotowym, nie uwzględniając relacji i wzajemnego wpływu pomiędzy poszczególnymi jednostkami. Czy zatem przedsiębiorczość powinno się badać wyłącznie przez pryzmat jednego podejścia, np. pokazując wykorzystanie programów unijnych do rozwoju organizacji, bez analizowania zaangażowania pracowników? Jedynie w 18 publikacjach na 101 analizowano relacje zachodzące pomiędzy podejściami do przedsiębiorczości, koncentrując się jednocześnie na dwóch jej rodzajach np. przedsiębiorczości kobiet oraz przedsiębiorczości własnej (2 publikacje), czy przedsiębiorczości administracyjnej i indywidualnej (2 publikacje). W opinii autorki prowadzenie badań uwzględniających wyłącznie jedno podejście jest niewystarczające. Badania prowadzone z obszaru przedsiębiorczości lub zawężone do określonego jej rodzaju powinny uwzględniać co najmniej dwa podejścia (czynniki) z czterech możliwych do zidentyfikowania, tj. ludzki, organizacyjny, gospodarczy i mieszany, czyli wzajemne przenikanie się wcześniej wyszczególnionych obszarów.

Przykład przedsiębiorczości publicznej pokazuje, jak z wielu różnych perspektyw można dokonywać analizy tego pojęcia. Przykładowo przedsiębiorczość publiczna może być analizowana przez pryzmat innych rodzajów przedsiębiorczości i ich wzajemnych wpływów, czy obszarów przenikania się. Dodatkowo obszarem zainteresowań mogą być różne rodzaje przedsiębiorstw, których podział można rozpocząć od organizacji non-profit, a skończyć na partnerstwie publiczno-prawnym.

Cechą łączącą człowieka i przedsiębiorstwo jest m.in. otoczenie, w którym ci pierwsi żyją, a drudzy funkcjonują. Biorąc pod uwagę, że przedsiębiorczość nierozerwalnie powiązana jest z wykorzystywaniem pojawiających się w otoczeniu szans, czy okazji, warto podjąć problematykę współczesnego świata skoncentrowaną obecnie na szeroko pojętym kryzysie. W przeciągu ostatnich lat można zaobserwować rosnącą skalę zjawisk związanych z coraz częstszym występowaniem sytuacji kryzysowych. Przykładowo można wymienić kryzys gospodar- 
czy w Stanach Zjednoczonych, czy pandemię COVID-19, która obiegła cały świat, a jej skutki dopiero zaczynają być odczuwalne. Mimo, że kryzys jest pojęciem o negatywnym brzmieniu, warto poddać głębszej analizie chociażby jego pozytywny wpływ na poszczególne rodzaje przedsiębiorczości.

\section{Literatura}

Bajgier-Kowalska, M., Tracz, M., Uliszak, R. (2016). Uwarunkowania rozwoju przedsiębiorczości na obszarach wiejskich na przykładzie gospodarstw agroturystycznych województwa małopolskiego. Przedsiębiorczość-Edukacja, 12, 256-273.

Bański, J. (2015). Uwarunkowania rozwoju przedsiębiorczości na wsi - wybrane zagadnienia. Roczniki Naukowe Ekonomii Rolnictwa i Rozwoju Obszarów Wiejskich, T. 102, z. 1, 59-69.

Baran, G., Bąk, J. (2016). Przedsiębiorczość jako proces stawania się. Przedsiębiorczość Międzynarodowa, 2(1), $83-98$.

Bieniok, H. (2016). Przedsiębiorczość i innowacyjność źródłem sukcesu osobistego i firmy. Studia Ekonomiczne. Zeszyty Naukowe Uniwersytetu Ekonomicznego w Katowicach, 278, 161.

Bratnicka, K. (2015). Twórcza przedsiębiorczość organizacyjna. Studia Ekonomiczne. Zeszyty Naukowe Uniwersytetu Ekonomicznego w Katowicach, 212, 24-34.

Chyba, Z. (2015). Rola potencjału technologicznego w kreowaniu przedsiębiorczości technologicznej. Kwartalnik naukowy o przedsiębiorstwie, 4, 31.

Ćwiklicki, M. (2015). W kierunku neo-biurokracji: o biurokracji we współczesnych koncepcjach zarządzania publicznego. MPRA Paper - Munich Personal RePEc Archive, 65, 345, 9.

Daszkiewicz, N. (2014). Przedsiębiorczość międzynarodowa jako nowy obszar badań w teorii internacjonalizacji. W: A. Budnikowski, D. Kuźniar D. (red.). Nowe procesy w gospodarce światowej. Wnioski dla Polski (s. 2014). Warszawa: Oficyna Wydawcza Szkoły Głównej Handlowej w Warszawie.

Faron, A., Maciejewski, M. (2018). Proprzedsiębiorcze działania Urzędu Pracy a oczekiwania osób bezrobotnych. Przedsiębiorczość i Zarządzanie, Tom XV, Zeszyt 10, Cz. I, 191.

Gaweł, A., Pietrzykowski, M. (2015). Edukacja akademicka w postrzeganiu przedsiębiorczości i kształtowaniu intencji przedsiębiorczych. Problemy Zarządzania, 13, 1(51), t. 2, 41-55.

Gąszczyk, R. (2015). Niefinansowe formy wspierania przedsiębiorczości przez państwo. W: Z. Cieślak, A. Kosieradzka-Federczyk (red.). Prace studialne Warszawskiego Seminarium Aksjologii Administracji. Nowe zjawiska w administracji publicznej. T. IV (s. 74). Piaseczno: Sowa Sp. z o.o.

Głód, G., Głód, W. (2017). Uwarunkowania innowacyjności w publicznych i niepublicznych jednostkach ochrony zdrowia. Studia Ekonomiczne, 183, cz. 1, 75.

Gromada, T. (2016). Przedsiębiorczość osób bezrobotnych południowej Wielkopolski w perspektywie projektów unijnych. W: E. Kowalczyk, G. Roszyk-Kowalska G. (red. nauk.). Człowiek w organizacji XXI wieku. Wyzwania dla współczesnego zarządzania (s. 10). Poznań: Wydawnictwo Uniwersytetu Ekonomicznego w Poznaniu.

Huczek, M. (2008). Przedsiębiorczość sektora publicznego. Zeszyty Naukowe Wyższej Szkoły Humanitas, Zarzqdzanie, 1, 20.

Jeżak, J. (2016). Rozwój przedsiębiorczości rodzinnej w Polsce na tle tendencji światowych. Przegląd Organizacji, 4, 52-59.

Kowalczyk, M., L. (2015). Zarządzanie strategiczne w jednostkach budżetowych. Zeszyty Naukowe Uniwersytetu Szczecińskiego. Finanse, Rynki Finansowe, Ubezpieczenia, 74(2), 473.

Mijal, A. (2016). Zachowanie przedsiębiorcze Polaków i formy wspomagania rozwoju przedsiębiorczości w Polsce. Zeszyty Naukowe Politechniki Częstochowskiej. Zarządzanie, 22, 47.

Musialik, G., Musialik, R. (2015). Zarządzanie sektorem publicznym a preferencje publiczne. Prace Naukowe Uniwersytetu Ekonomicznego we Wrocławiu, 403, 174.

Nowicka, J. (2014). Przedsiębiorczość indywidualna i korporacyjna wobec problemu wypalenia zawodowego. Humanizacja pracy, 3(277), 131.

Pacut, A. (2015). Rozwój przedsiębiorczości społecznej - istota i kierunki analizy. Ekonomia Społeczna, 1, 7-20.

Piecuch, T. (2018). Rozwój przedsiębiorczości korporacyjnej perspektywa indywidualna i organizacyjna. Rzeszów: Oficyna Wydawnicza Politechniki Rzeszowskiej.

Pietrewicz, J. W., Sobiecki, R. (2016). Przedsiębiorczość sharing economy. W: M. Poniatowska-Jaksch, R. Sobiecki (red.). Sharing Economy (gospodarka współdzielenia) (s.11-26). Warszawa: Wydawnictwo SGH. 
Piróg, D. (2015). Kompetencje z zakresu przedsiębiorczości: rozważania teoretyczne i ich ilustracje w obszarze szkolnictwa wyższego Przedsiębiorczość-Edukacja, 11, 11.

Piwowar-Sulej, K., Kwil, I. (2018). Przedsiębiorczość, przedsiębiorczość akademicka i technologiczna. innowacyjność - próba systematyzacji. Przegląd Organizacji, 7, 19.

Płaziak, M., Rachwał, T. (2015). „Przedsiębiorczy region” - zarys koncepcji w świetle analizy roli przedsiębiorczości w krajowej strategii rozwoju regionalnego. Przedsiębiorczość-Edukacja, 11, 37-49.

Polcyn, J.: (2014). Przedsiębiorczość w sektorze publicznym w Polsce na przykładzie rynku edukacyjnego. W: D. J. Mierzejewski, J. Polcyn (red.). Gospodarka w warunkach integracji europejskiej. Seria: Czwartki u Ekonomistów, Tom II (s. 158). Piła: Wydawnictwo Wyższej Szkoły Zawodowej im. Stanisława Staszica w Pile.

Popowska, M. (2018). Przedsiębiorczość społeczna jako klucz do skutecznej edukacji przedsiębiorczej na społecznie odpowiedzialnym uniwersytecie. Horyzonty Wychowania, 17, nr 42, 207.

Roman, M., Niedziółka, A. (2017). Agroturystyka jako forma przedsiębiorczości na obszarach wiejskich. Warszawa: Wydawnictwo SGGW.

Roslan-Karaś, A., Wasilczuk, J. E. (2015). Przedsiębiorczość internetowa w blogosferze. Zeszyty Naukowe Uniwersytetu Szczecińskiego. Ekonomiczne Problemy Usług, 116, 151.

Sadowska, M. (2016). Edukacja w zakresie przedsiębiorczości w polskim systemie kształcenia oraz w państwach europejskich. Przedsiębiorczość Międzynarodowa, 2(1), 149-164.

Sasinowski, H. (2015). Zarządzanie publiczne jako element innowacyjności i przedsiębiorczości w gospodarce turystycznej. Ekonomia i środowisko, 4(55), 86.

Sikorska-Wolak, l., Cyburt, A. (2015). Pozyskiwanie i wykorzystanie funduszy Unii Europejskiej jako przejaw przedsiębiorczości jednostek samorządu terytorialnego. Turystyka i Rozwój Regionalny, 4, 108.

Stachowicz, J. (2015). Przedsiębiorczość technologiczna kluczową siłą rozwoju przedsiębiorstw wysokich technologii. Zeszyty Naukowe Politechniki Ślaskiej. Seria: Organizacja i Zarzadzanie, z. 83, 627-639.

Strojny, J., Chodober, M. (2016). Badanie poziomu przedsiębiorczości indywidualnej na grupie studentów studiów magisterskich Wydziału Zarządzania Politechniki Rzeszowskiej, Przedsiębiorczość-Edukacja, 12, 418.

Sułkowski, Ł., Marjański A. (2017). Przedsiębiorczość w dobie wyzwań rozwojowych. Przedsiębiorczość i Zarzqdzanie, XVIII, 12, cz. I, s. 7.

Tracz, M. (2015). Przedmiot podstawy przedsiębiorczości w opinii uczniów i nauczycieli - studium porównawcze. Przedsiębiorczość-Edukacja, 11, 391-400.

Urbaniec, M. (2018). Rola przedsiębiorczości w kontekście zrównoważonego rozwoju. Przedsiębiorczość-Edukacja, 14, 27.

Ustawa z dnia 15 kwietnia 2011 r. o działalności leczniczej (Dz.U. 2011 nr 112 poz. 654)

Wach, K. (2015). Przedsiębiorczość jako czynnik rozwoju społeczno-gospodarczego: przegląd literatury. Przedsiębiorczość-Edukacja, 11, 26-28.

Walecka, A. (2016). Kapitał relacyjny przedsiębiorstw w kryzysie. Prace Naukowe Uniwersytetu Ekonomicznego we Wrocławiu, 422, 158-170.

Wiśniewska, M. (2018). Wartość publiczna aglomeracyjnego transportu kolejowego na przykładzie łódzkiej kolei aglomeracyjnej. Prace Naukowe Uniwersytetu Ekonomicznego we Wrocławiu, $517,112$.

Wodecka-Hyjek, A. (2012). Wybrane aspekty rozwoju przedsiębiorczości sektora publicznego. W: B. Mikuła (red.): Historia i perspektywy nauk o zarządzaniu. Księga pamiątkowa dla uczczenia jubileuszu 40-lecia pracy naukowo-dydaktycznej Prof. zw. dra hab. Arkadiusza Potockiego (s. 426), Kraków: Fundacja Uniwersytetu Ekonomicznego w Krakowie.

Wodecka-Hyjek, A. (2018). Przedsiębiorczość publiczna przesłanką kształtowania modeli biznesu w sektorze publicznym. Prace Naukowe Uniwersytetu Ekonomicznego we Wrocławiu, 538, 456.

Wuwer, A. (2018). Sprawozdanie z Międzynarodowej Interdyscyplinarnej Konferencji Naukowej Subsydiarność - uwarunkowania, regulacje i praktyka w stulecie niepodległości Państwa Polskiego. Śląskie Studia Historyczno-Teologiczne, 51, 2, 515.

Zastempowski, M. (2016): Innowacyjność małych i średnich przedsiębiorstw w warunkach kryzysu gospodarczego.Toruń: Wydawnictwo Naukowe Uniwersytetu Mikołaja Kopernika

Zioło, Z. (2016). Przedsiębiorczość w rozwoju układów lokalnych. Przedsiębiorczość-Edukacja, 2, 6-17.

\section{Multidimensionality of entrepreneurship in Polish research literature}

Summary: The concept of entrepreneurship is a multidimensional concept and can be viewed through the prism of all experiences as well as the way of enterprises functioning. To show the interpenetration of different approaches to the definition of entrepreneurship and its types, with particular emphasis on public 
entrepreneurship, as an area of occurrence of all types of entrepreneurship. The review article is the result of a query of the current literature in the scope of the problem undertaken, the study also uses deductive inference and the mind map technique. In the literature, many attempts have been made to narrow down this concept more and more, as indicated by types of entrepreneurship that are the research object. Based on the literature analysis, the multidimensionality of the concept of entrepreneurship was demonstrated. The concept of entrepreneurship is a multidimensional concept and can be viewed through the prism of all aspects of human life as well as the enterprises functioning. Research on entrepreneurship should refer to three dimensions, i.e. individual personal characteristics, organization and the mutual influence of an organization on a person (not only an employee) and a person on the organization.

Keywords: entrepreneurship, types of entrepreneurship, public entrepreneurship JEL codes: L26, L30

\section{Informacje o autorce}

\section{Karolina Wielicka-Gańczarczyk, dr inż.}

ORCID: 0000-0001-5475-6661

Katedra Zarządzania i Logistyki

Wydział Organizacji i Zarządzania

Politechnika Śląska

ul. Roosevelta 26-28, 41-800 Zabrze

e-mail: karolina.wielicka-ganczarczyk@polsl.pl

\section{Prawa autorskie i licencja / Copyright and License}

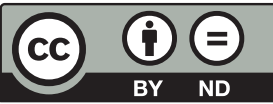

Publikacja na licencji Creative Commons Uznanie autorstwa Użycie niekomercyjne - Bez utworów zależnych 4.0 Międzynarodowe (CC BY-ND 4.0) http://creativecommons.org/licenses/by-nc-nd/4.0/deed/pl

This work is published under the terms of the Creative Commons

Attribution - NoDerivetives International (CC BY-ND 4.0) License http://creativecommons.org/licenses/by-nc-nd/4.0

Wydane przez Uniwersytet Ekonomiczny w Krakowie. Małopolska Szkoła Administracji Publicznej

Published by Cracow University of Economics - Krakow, Poland. Małopolska School of Public Administration of the Cracow University of Economics 